\title{
Fotografía
}

\section{Ponte en su lugar}

\section{Tamara Blanco Pérez}

Estudiante Grado en enfermería, Escuela de enfermería de Guadalajara, Universidad de Alcalá Autor correspondencia: tamara1998.tb@gmail.com

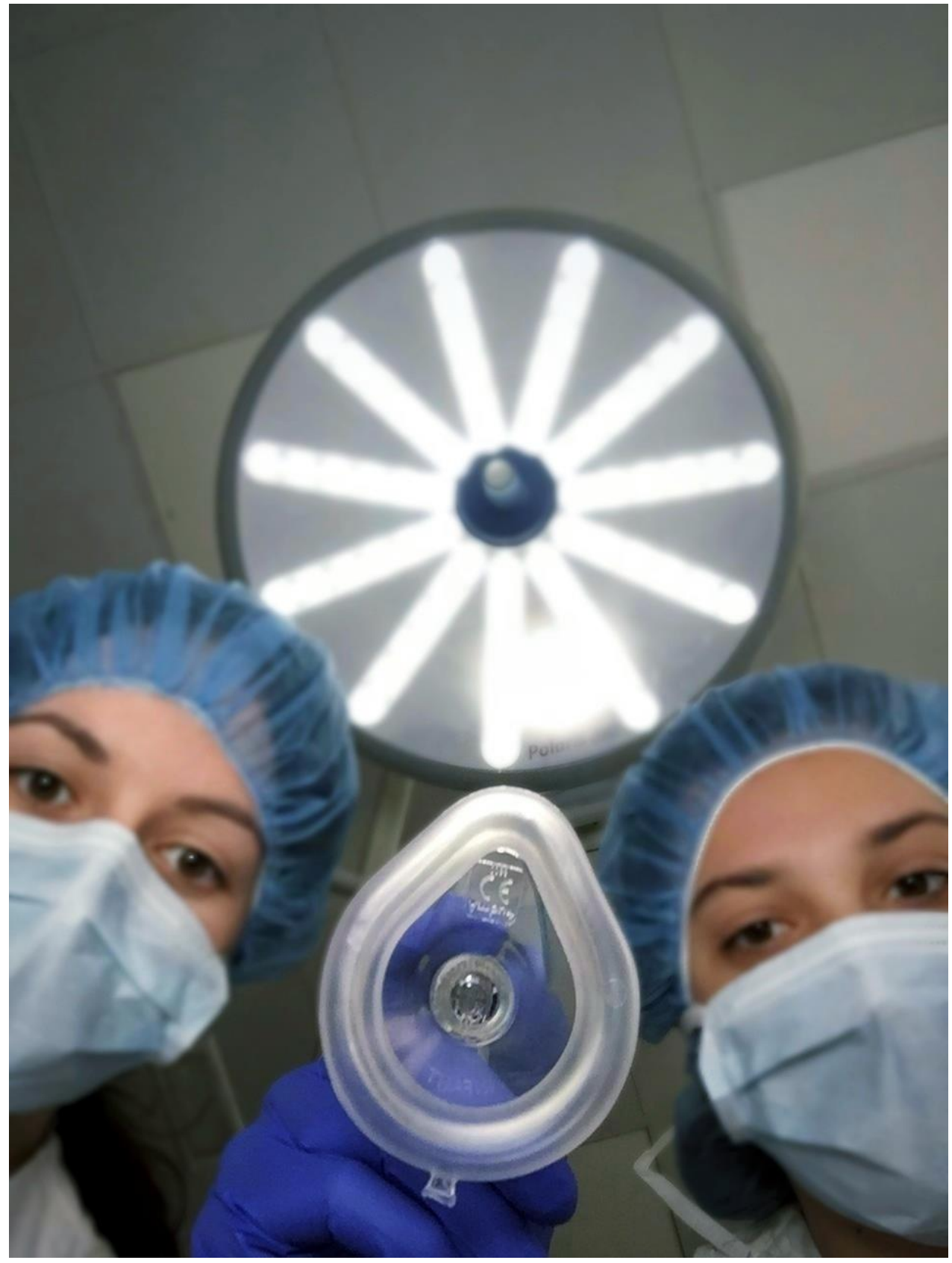

Primer Premio del Concurso de Fotografía "50 Aniversario Enfermería Guadalajara"

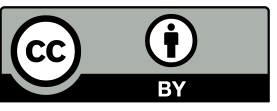

(C) 2019 por los autores; Esta obra está sujeta a la licencia de Reconocimiento 4.0 Internacional de Creative Commons. Para ver una copia de esta licencia, visite http://creativecommons.org/licenses/by-nc-nd/4.0/. 